\title{
Pain and self-reported health in Canadian children
}

\author{
Adam van Dijk MSc ${ }^{1}$, Patricia A McGrath $\mathrm{PhD}^{2,3}$, William Pickett $\mathrm{PhD}^{1}$, Elizabeth G Van Den Kerkhof RN DrPH ${ }^{1,4}$
}

\begin{abstract}
A van Dijk, PA McGrath, W Pickett, EG Van Den Kerkhof. Pain and self-reported health in Canadian children. Pain Res Manage 2008;13(5):407-411.
\end{abstract}

BACKGROUND: Despite increasing attention to the epidemiology of pain, relatively little is known about the association between pain and health in children. In particular, no studies have examined this relationship in the general population of children in Canada.

OBJECTIVES: To assess the association between self-reported pain experiences and health in school children in southeastern Ontario. Health measures included perceived health status, psychological complaints and satisfaction with school.

METHODS: A total of 495 nine- to 13-year-old school children completed the Pain Experience Interview - Short Form and healthrelated questions from the Health Behaviour in School-aged Children questionnaire.

RESULTS: Of the 495 children in the present study, $8 \%$ rated their health as 'fair' to 'poor', 56\% reported experiencing at least one of four psychological symptoms more than once a week and $24 \%$ said they disliked school. The strongest associations existed between headaches and poor self-rated health $(\mathrm{OR}=10.1 ; 95 \% \mathrm{CI} 1.3$ to $78.3)$, recurrent pain and psychological outcomes $(\mathrm{OR}=3.6 ; 95 \%$ CI 2.0 to 6.3 ), and recurrent pain and disliking school (OR=3.6; $95 \%$ CI 1.9 to 6.7 ).

DISCUSSION: These findings indicate that common childhood pains are associated with childhood health. Further studies are needed to assess the causal relationship between pain and health in children, to obtain a more comprehensive understanding of the personal and economic impact of childhood pain, and to monitor changes in the lives of children living with chronic pain.

Key Words: Children; Chronic pain; Epidemiological study; Impact; Pain experience interview; Recurrent pain

Dain is a significant societal problem. Increasing worldwide attention has focused on the prevalence of varied pain problems in children (1) and the impact (personal and economic) of pain on children and their families (2,3). In Canada, the total economic burden of musculoskeletal pain conditions and injuries is as high as $\$ 17.8$ billion and $\$ 14.3$ billion, respectively (data from 1993) (4). A study conducted in southeastern Ontario found that 37\% (395 of 1067) of adults reported chronic pain (pain lasting longer than 90 days). Fair or poor self-rated health, depression and increased health care use were associated with more pain (5). Common pain conditions (eg, headaches, back pain and musculoskeletal

\section{Douleur et auto-rapport de santé chez les enfants canadiens}

HISTORIQUE : Malgré l'attention grandissante que suscite l'épidémiologie de la douleur, on en connaît relativement peu sur le lien entre la douleur et la santé chez les enfants. Aucune étude n'a analysé ce lien en particulier dans la population pédiatrique canadienne générale. OBJECTIF : Évaluer le lien entre la douleur auto-rapportée et la santé chez des enfants d'âge scolaire du Sud-Est de l'Ontario. Les paramètres de la santé incluaient l'état de santé perçu, les problèmes psychologiques et la satisfaction à l'école.

MÉTHODE : En tout, 495 élèves de neuf à 13 ans ont répondu à un questionnaire bref sur l'expérience douloureuse et à des questions reliées à la santé tirées du questionnaire Health Behaviour in School-aged Children.

RÉSULTATS : Parmi les 495 enfants de la présente étude, $8 \%$ ont qualifié leur santé de passable à médiocre, $56 \%$ ont dit avoir éprouvé au moins l'un de quatre symptômes psychologiques plus d'une fois par semaine et $24 \%$ ont dit ne pas aimer l'école. Les liens les plus solides ont été observés entre les maux de tête et un piètre état de santé auto-rapporté $(\mathrm{RR}=10,1$; IC à $95 \%, 1,3$ à 78,3), la douleur récurrente et les problèmes psychologiques ( $\mathrm{RR}=3,6$; IC à $95 \%, 2,0$ à 6,3) et la douleur récurrente et le désintérêt pour l'école ( $R R=3,6$; IC à $95 \%, 1,9$ à 6,7). DISCUSSION : Ces observations indiquent que les douleurs infantiles courantes sont associées à l'état de santé des enfants. Il faudra procéder à d'autres études pour évaluer le lien de cause à effet entre la douleur et la santé chez les enfants pour mieux comprendre l'impact personnel et économique de la douleur chez les enfants et pour mesurer les changements qui surviennent dans la vie d'enfants aux prises avec la douleur chronique.

\footnotetext{
${ }^{1}$ Department of Community Health and Epidemiology, Queen's University, Kingston; ${ }^{2}$ Divisional Centre of Pain Management and Pain Research, Hospital for Sick Children; ${ }^{3}$ Department of Anesthesiology, University of Toronto, Toronto; ${ }^{4}$ Department of Anesthesiology and School of Nursing, Queen's University, Kingston, Ontario

Correspondence: Dr Elizabeth Van Den Kerkhof, Queen's University, Kingston General Hospital, 76 Stuart Street, Kingston, Ontario K7L 2 V7.

Telephone 613-549-6666 ext 3964,fax 613-548-1375, e-mail ev5@queensu.ca
} 


\begin{tabular}{|l|c|c|c|}
\hline $\begin{array}{l}\text { Intensity } \\
\text { of headache }\end{array} \quad$ in past month & 0 & 1 & $2+$ \\
\hline None & 0 & 0 & 0 \\
\hline Mild (little bit, slight, mild) & 0 & 1 & 2 \\
\hline Medium (moderate) & 0 & 2 & 3 \\
\hline Strong (a lot, strong, intense) & 0 & 3 & 4 \\
\hline
\end{tabular}

Figure 1) Derived Headache Index. Schema and scoring index based on frequency and intensity of headaches in the past month from the Pain Experience Interview - Short Form. Adapted from formative work by Hartling et al (20)

in young adults (6). Musculoskeletal symptoms developed at an early age can lead to chronic pain and depression in adulthood. These both have economic and societal implications that underscore the importance of early prevention (7-9). A study conducted in the Netherlands (10) followed a populationbased cohort of 987 children 0 to 18 years of age for two years to examine chronic benign pain, and concluded that these pains persisted in $30 \%$ to $45 \%$ of the study population. They also examined the consequences of pain and found that health status, school absence, health care use, medication use and interference in daily activities were affected (10). Children with migraine headaches report additional somatic symptoms more often than children without headaches (11). Also, children with varied chronic and recurrent pain conditions experience sleep disturbance, dizziness, worsening anxiety or mood, and emotional distress (12-16). Studies are needed to better understand the nature of pain and its relationship to childhood health in Canada.

We recently reported that $57 \%$ of schoolchildren in our Canadian study reported frequent and disabling pain (17). At that time, we asked about selective health outcomes. The objective of the present analysis was to assess the association between pain experiences and perceived health status, psychological complaints and satisfaction with school in a sample of school children in southeastern Ontario.

\section{METHODS}

\section{Design}

In the spring of 2005 , a survey was conducted in a cohort of school children nine to 13 years of age to obtain lifetime and point prevalence of acute, recurrent and chronic pain (17). Children attending 20 of the 95 elementary schools in the Kingston and Belleville (Ontario) areas completed the selfadministered Pain Experience Interview - Short Form (PEISF) (17) and health-related questions from the Health Behaviour in School-aged Children (HBSC) questionnaire (18). Ethical approval was obtained from the Queen's University Health Sciences and affiliated Teaching Hospitals Research Ethics Board, the Limestone District School Board and the Algonquin and Lakeshore Catholic District School Board. All children in grades 5 and 6 in participating schools were approached for inclusion in the study. This age group was selected because the majority would not yet have reached puberty, and could potentially be followed as they progressed through puberty and adolescence. They were also easily accessible from an administrative perspective in that they could be captured in one school system (ie, elementary), making questionnaire administration more manageable. Fortyeight schools were purposefully selected to represent varying socioeconomic levels and geographic areas. Further elaboration of the survey process can be found in van Dijk et al (17).

\section{Questionnaire}

The current study employed the PEI-SF (17), a self-report questionnaire capturing information about acute, recurrent and long-lasting pain in children. The PEI-SF is based on the Pain Experience Interview (19). The latter was developed for use in clinical populations, while the PEI-SF is intended for use in the general population. Three questions were added from the World Health Organization's HBSC questionnaire (18), which asked children about their self-rated health, feelings about school and ongoing psychological health complaints. Additional demographic information collected included school, school board and postal code. The latter was used as a proxy for rural versus urban school settings.

\section{Pain experience}

The association between four specific pain complaints (headaches, persistent pain problems [recurrent and long-lasting pain] and strong acute pain experiences) and childhood health characteristics was examined. These pain measures were chosen a priori and are based on previous work $(17,19)$ that highlighted common pains that children experience.

Headache experience was classified into five levels using a matrix based on pain frequency and intensity (Figure 1) (20). Recurrent pain experience was classified as none, one, or two or more times in the past month. The objective of the question about long-lasting pain was to identify children who may be experiencing chronic pain. Children were asked to describe their long-lasting pain experiences with respect to duration (longer than a few weeks), type and current status. They were asked to list and comment on these pains and were given an explanation to differentiate these pains from recurrent pains. Based on this information, three categories were created: no pain, pain (not chronic) and chronic pain. No pain referred to children who did not have any long-lasting pain. Pain (not chronic) was defined as pain lasting less than a few weeks, pain that had not occurred in the past week or pain that was clearly not chronic. Chronic pain was defined as pain lasting more than a few weeks that was present at least once in the past week. Type of pain was also taken into consideration when defining chronic pain. Finally, children were asked to report on three strong acute pains related to forms of major trauma - broken bones, serious accident or injury, and burns. These three items have been rated as higher in pain intensity, pain affect and pain duration than other acute pains (17). The frequency of these strong acute pain experiences in the past month was categorized into none, one or two (no child had all three).

\section{Self-reported health measures}

Self-rated health was reported as excellent, good, fair or poor, and was dichotomized into 'excellent/good' and 'fair/poor' for the multivariable analysis. The four psychological questions asked children how often they had experienced feeling low, irritable or bad temper, feeling nervous, and difficulties falling asleep. This scale is based on formative work by King et al (21) and is part of the eight-item HBSC symptom checklist. Each item had five response options which were then dichotomized 
TABLE 1

Frequency and percentage of representative pain experiences stratified by sex for children in grades 5 and 6

\begin{tabular}{|c|c|c|c|c|c|}
\hline \multirow[b]{2}{*}{ Variable* } & \multicolumn{2}{|c|}{ Boys } & \multicolumn{2}{|c|}{ Girls } & Total \\
\hline & $\mathbf{n}$ & $\%$ & $\mathrm{n}$ & $\%$ & $\%$ \\
\hline
\end{tabular}

Headache index ${ }^{\dagger}$

\begin{tabular}{lrrrrrr} 
None & 56 & 25 & 53 & 21 & 109 & 23 \\
One or two & 94 & 42 & 91 & 36 & 185 & 39 \\
Three or four & 72 & 33 & 108 & 43 & 180 & 38 \\
Recurrent pain & & & & & & \\
$\quad$ None & 90 & 42 & 95 & 38 & 185 & 39 \\
One & 91 & 42 & 110 & 43 & 201 & 43 \\
Two or more & 35 & 16 & 48 & 19 & 83 & 18 \\
Long-lasting pain & & & & & & \\
None & 127 & 56 & 129 & 50 & 256 & 53 \\
Not chronic & 91 & 41 & 112 & 44 & 203 & 42 \\
Chronic & 7 & 3 & 15 & 6 & 22 & 5 \\
Strong acute pain & & & & & & \\
None & 154 & 66 & 136 & 52 & 290 & 59 \\
One & 65 & 28 & 108 & 41 & 173 & 35 \\
Two & 13 & 6 & 19 & 7 & 32 & 6 \\
\hline
\end{tabular}

$n$ may not add up to 495 due to missing data. *Refer to Methods section for further explanation of each independent variable; ${ }^{\dagger}$ Refer to Figure 1 for scale

into 'once a week or less' and 'more than once a week' (22). A composite measure of the four psychological health symptoms (henceforth referred to as 'adverse psychological outcome') was used in the multivariable analysis. Feelings about school were dichotomized into 'I like it a lot/I like it a bit' and 'I dislike it a bit/I dislike it a lot.'

\section{Statistical methods}

Statistical analyses were conducted using the SAS system (SAS Institute Inc, USA) for Windows (version 8). Demographic characteristics were summarized using descriptive statistics. Pain experience (exposure) variables were expressed as raw frequencies and percentages, while contingency table analyses were used to examine variations in each pain experience measure in relation to each health measure. Logistic regression was used to analyze the association between pain and health, with health being the dependent variable. A total of 12 regression models were calculated. ORs and 95\% CIs were adjusted for age, sex, separate or public school board, and urban or rural status.

\section{RESULTS}

Response and demographic data

A total of 1199 consent forms were sent out and 534 were returned, yielding a consent return rate of $45 \%$. Of the 534 returned consent forms, 495 children agreed to participate (93\%). Fifty-three per cent of the participants were female. Consistent with their grades, the majority of respondents were $10(37 \%)$ or $11(44 \%)$ years of age, with a range of nine to 13 years of age (17).

\section{Pain experiences}

Table 1 shows the distributions of the four pain exposures stratified by sex for the study population. Headaches were the
TABLE 2

Frequency and percentage of selected health variables stratified by sex for children in grades 5 and 6

\begin{tabular}{|c|c|c|c|c|c|c|}
\hline \multirow[b]{2}{*}{ Variable } & \multicolumn{2}{|c|}{ Boys (n=232) } & \multicolumn{2}{|c|}{ Girls (n=261) } & \multicolumn{2}{|c|}{ Total } \\
\hline & $\mathbf{n}$ & $\%$ & $\mathbf{n}$ & $\%$ & $\mathbf{n}$ & $\%$ \\
\hline \multicolumn{7}{|l|}{ Self-rated health } \\
\hline Excellent & 86 & 39 & 108 & 41 & 194 & 40 \\
\hline Good & 116 & 52 & 134 & 52 & 250 & 52 \\
\hline Fair & 16 & 7 & 18 & 7 & 34 & 7 \\
\hline Poor & 4 & 2 & 0 & 0 & 4 & 1 \\
\hline \multicolumn{7}{|l|}{ Psychological items } \\
\hline \multicolumn{7}{|l|}{ Feeling low } \\
\hline Once a week or less & 179 & 82 & 215 & 84 & 394 & 83 \\
\hline More than once a week & 40 & 18 & 42 & 16 & 82 & 17 \\
\hline \multicolumn{7}{|l|}{ Irritable or bad temper } \\
\hline Once a week or less & 159 & 73 & 181 & 71 & 340 & 72 \\
\hline More than once a week & 58 & 27 & 75 & 29 & 133 & 28 \\
\hline \multicolumn{7}{|l|}{ Feeling nervous } \\
\hline Once a week or less & 172 & 79 & 199 & 79 & 371 & 79 \\
\hline More than once a week & 46 & 21 & 54 & 21 & 100 & 21 \\
\hline \multicolumn{7}{|l|}{ Difficulties falling asleep } \\
\hline Once a week or less & 148 & 68 & 174 & 67 & 322 & 67 \\
\hline More the once a week & 71 & 32 & 85 & 33 & 156 & 33 \\
\hline \multicolumn{7}{|l|}{ Any psychological item } \\
\hline Once a week or less & 96 & 44 & 113 & 44 & 209 & 44 \\
\hline More than once a week & 124 & 56 & 146 & 56 & 270 & 56 \\
\hline \multicolumn{7}{|l|}{ School satisfaction } \\
\hline Like it a lot & 56 & 26 & 102 & 38 & 158 & 33 \\
\hline Like it a bit & 97 & 44 & 108 & 41 & 205 & 43 \\
\hline Dislike it a bit & 34 & 16 & 36 & 14 & 70 & 14 \\
\hline Dislike it a lot & 31 & 14 & 19 & 7 & 50 & 10 \\
\hline
\end{tabular}

most prevalent pain exposure reported by children, with $77 \%$ having a score of at least 1 on the Derived Headache Index (Figure 1). Sixty per cent of children reported having one or more recurrent pains, and 22 children $(5 \%)$ were classified as having chronic pain. Boys and girls reported similar levels of recurrent and long-lasting pain experiences. Forty-eight per cent of girls and $34 \%$ of boys reported at least one of the three strong acute pain experiences in the past month.

\section{Health outcomes}

Table 2 shows the distributions of the three health outcome measures stratified by sex. The majority (92\%) of children reported 'good' or 'excellent' health. Fifty-six per cent reported experiencing at least one of the psychological items more than once a week (adverse psychological outcome) (Table 2). Twenty-four per cent of participants reported disliking school. Twenty-one per cent of girls and 30\% of boys reported disliking school. Pearson correlation coefficients were calculated between each of the three outcomes with no significant associations found (data not shown).

Relationship between pain experiences and health outcomes Pain experience was consistently associated with adverse health outcomes (Tables 3 and 4). Strong and consistent risk gradients were observed between the pain exposures and most health measures, after adjustment for sex, age and school setting. 
TABLE 3

The association between pain and adverse health in children: Frequency of negative responses to health outcomes in relationship to pain experiences

\begin{tabular}{|c|c|c|c|c|c|}
\hline \multirow[b]{2}{*}{ Exposure variable } & \multicolumn{2}{|c|}{ Total } & \multirow{2}{*}{$\begin{array}{l}\text { Fair or poor self-rated health, } \\
\qquad \%(95 \% \mathrm{Cl})\end{array}$} & \multirow{2}{*}{$\begin{array}{c}\text { Adverse } \\
\text { psychological outcome, } \\
\%(95 \% \mathrm{Cl})\end{array}$} & \multirow{2}{*}{$\begin{array}{c}\text { Dislike school, } \\
\%(95 \% \mathrm{Cl})\end{array}$} \\
\hline & $\mathbf{n}$ & $\%$ & & & \\
\hline \multicolumn{6}{|l|}{ Headache index } \\
\hline None & 109 & 23 & $2(0-5)$ & $39(30-48)$ & $23(15-31)$ \\
\hline One or two & 185 & 39 & $10(6-14)$ & $52(45-59)$ & $23(17-29)$ \\
\hline Three or four & 180 & 38 & $9(5-13)$ & $70(63-77)$ & $29(22-36)$ \\
\hline \multicolumn{6}{|l|}{ Recurrent pain } \\
\hline None & 185 & 39 & $4(1-7)$ & $40(33-47)$ & $15(10-20)$ \\
\hline One & 201 & 43 & $10(6-14)$ & $67(60-74)$ & $29(23-35)$ \\
\hline Two or more & 83 & 18 & $10(4-16)$ & $70(60-80)$ & $37(27-47)$ \\
\hline \multicolumn{6}{|l|}{ Long-lasting pain } \\
\hline No pain & 256 & 53 & $7(4-10)$ & $50(44-56)$ & $23(18-28)$ \\
\hline Not chronic & 203 & 42 & $8(4-12)$ & $64(57-71)$ & $26(20-32)$ \\
\hline Chronic pain & 22 & 5 & $10(0-23)$ & $67(47-87)$ & $43(22-64)$ \\
\hline \multicolumn{6}{|l|}{ Strong acute pain } \\
\hline None & 290 & 59 & $8(5-11)$ & $52(46-58)$ & $26(21-31)$ \\
\hline One & 173 & 35 & $8(5-13)$ & $62(55-69)$ & $23(16-28)$ \\
\hline Two & 32 & 6 & $3(0-8)$ & $67(50-80)$ & $28(15-45)$ \\
\hline
\end{tabular}

TABLE 4

Association between various pain experiences and negative 'self-rated health', 'psychological' and 'school perception' outcomes

\begin{tabular}{|c|c|c|c|}
\hline $\begin{array}{l}\text { Exposure } \\
\text { variable }\end{array}$ & $\begin{array}{l}\text { Fair or poor } \\
\text { self-rated health*, } \\
\text { Adjusted OR } \\
(95 \% \mathrm{Cl})\end{array}$ & $\begin{array}{c}\text { Adverse } \\
\text { psychological } \\
\text { outcome*, } \\
\text { Adjusted OR } \\
(95 \% \mathrm{Cl})\end{array}$ & $\begin{array}{c}\text { Dislike } \\
\text { school*, } \\
\text { Adjusted OR } \\
(95 \% \mathrm{Cl})\end{array}$ \\
\hline \multicolumn{4}{|l|}{ Headache index } \\
\hline None & 1.0 & 1.0 & 1.0 \\
\hline One or two & $11.1(1.4-84.5)$ & $1.8(1.1-2.9)$ & $1.1(0.6-1.9)$ \\
\hline Three or four & $10.1(1.3-78.3)$ & $3.7(2.2-6.2)$ & $1.6(0.9-2.9)$ \\
\hline \multicolumn{4}{|l|}{ Recurrent pain } \\
\hline None & 1.0 & 1.0 & 1.0 \\
\hline One & $2.5(1.1-5.9)$ & $3.0(2.0-4.6)$ & $2.2(1.3-3.7)$ \\
\hline Two or more & $2.7(0.9-7.5)$ & $3.6(2.0-6.3)$ & $3.6(1.9-6.7)$ \\
\hline \multicolumn{4}{|c|}{ Long-lasting pain } \\
\hline No pain & 1.0 & 1.0 & 1.0 \\
\hline Not chronic & $0.9(0.4-1.9)$ & $1.9(1.3-2.8)$ & $1.3(0.8-2.0)$ \\
\hline Chronic & $1.5(0.2-12.3)$ & $2.0(0.8-5.2)$ & $2.7(1.0-7.1)$ \\
\hline \multicolumn{4}{|c|}{ Strong acute pain } \\
\hline None & 1.0 & 1.0 & 1.0 \\
\hline One & $1.1(0.5-2.2)$ & $1.6(1.1-2.3)$ & $1.0(0.6-1.5)$ \\
\hline Two & $0.4(0.1-3.3)$ & $1.9(0.9-4.0)$ & $1.2(0.5-2.8)$ \\
\hline
\end{tabular}

Hosmer and Lemeshow goodness of fit, $P \geq 0.1$ for all models (range 0.1 to 0.80). *Adjusted for sex, age, school setting and school board

Pain was associated with poor self-rated health, psychological symptoms and unhappiness with school experiences.

\section{Significant trends}

As pain exposure increased in duration and intensity, children's perceived health status declined (Table 3 ). There was a consistent increase in the magnitude of association between increasing number of recurrent pains and adverse health for all three health measures. Children with probable chronic pain compared with those with no pain were significantly more likely to report adverse psychological effects and dislike of school. Headache was also consistently associated with adverse health for all three health measures.

The adverse psychological variable had the strongest and most consistent risk gradient with pain (Table 4). Children experiencing a high score on the headache index or experiencing two or more recurrent pains were nearly four times more likely to report an adverse psychological item $(\mathrm{OR}=3.7 ; 95 \%$ CI 2.2 to 6.2 and $\mathrm{OR}=3.6 ; 95 \%$ CI 2.0 to 6.3 , respectively). Twenty-two children with probable chronic pain were identified (Table 1). These children were more likely to report an adverse psychological outcome $(\mathrm{OR}=2.0 ; 95 \% \mathrm{CI} 0.8$ to 5.2$)$ and a dislike of school (OR=2.7; 95\% CI 1.0 to 7.1) (Table 4). Children with chronic pain were also cross-referenced with those reporting intense and frequent headaches; it was found that only one of the 22 children reported chronic pain and headaches. Thirty-eight children reported poor or fair perceived health status. The odds of poor or fair perceived health status were greater than 10 for any score on the headache index; however, the $95 \%$ CIs (1.3 to 84.5$)$ for this estimate was large due to the small sample size (Table 4).

\section{DISCUSSION}

This is one of the first school-based studies to examine the associations between pain and self-reported health in children in North America. Children who reported two or more recurrent pains were more likely to report fair or poor selfrated health $(\mathrm{OR}=2.7 ; 95 \% \mathrm{CI} 0.9$ to 7.5$)$, adverse psychological outcomes $(\mathrm{OR}=3.6 ; 95 \%$ CI 2.0 to 6.3$)$, and a dislike of school $(\mathrm{OR}=3.6 ; 95 \% \mathrm{CI} 1.9$ to 6.7$)$ than children reporting no recurrent pain. Particularly strong associations existed between headache frequency and intensity and health, while weaker associations were found between strong acute pain or 
chronic pain and health (Table 4). Few studies have examined the relationship between pain and health in children. Our findings are consistent with international studies. Two European studies $(7,9)$ reported that students eight to 17 years of age sometimes stayed home from school because of pain, while another study (23) found that pain increased a child's odds of daytime tiredness ( $\mathrm{OR}=1.9 ; 95 \%$ CI 1.2 to 3.0). A study of German children (3) reported that pain caused sleep problems, eating problems and school absence. This study also reported that restrictions in daily living attributed to pain increased with age, suggesting that unrelieved pain experiences may affect children into adolescence.

Study limitations include the over-representation of schools from the separate school system. We do not believe this introduced any systematic bias because there were no significant differences in prevalence or risk estimates between the two school populations (further discussion on this limitation is reported elsewhere [17]). The poor consent return rate may have biased our sample. In addition, some analyses were limited by small cell sizes and the associated loss of statistical power (eg, correlations between the headache index and self-rated health). Although the sampling strategy that was employed does not lend itself to generalizing the results, observed reports of perceived health, feelings about school and psychological symptoms are similar to national estimates from the 2001 to 2002 Canadian HBSC questionnaire (24). This speaks to the

\section{REFERENCES}

1. Van Den Kerkhof EG, van Dijk A. Prevalence of chronic pain disorders in children. In: Schmidt RF, Willis WW, eds.

Encyclopedic Reference of Pain. Heidelberg: Springer, 2006.

2. Stewart WF, Ricci JA, Chee E, Morganstein D, Lipton R. Lost productive time and cost due to common pain conditions in the US workforce. JAMA 2003;290:2443-54.

3. Roth-Isigkeit A, Thyen U, Stoven H, Schwarzenberger J, Schmucker P. Pain among children and adolescents: Restrictions in daily living and triggering factors. Pediatrics 2005;115:e152-62.

4. Canadian Pain Consortium. Canadian Consortium on Pain Mechanism Diagnosis and Management. <http://www.curepain.ca/ final.htm $>$ (Version no longer current).

5. Tripp DA, Van Den Kerkhof EG, McAlister M. Prevalence and determinants of pain and pain-related disability in urban and rural settings in southeastern Ontario. Pain Res Manage 2006;11:225-33.

6. Brattberg G. Do pain problems in young school children persist into early adulthood? A 13-year follow-up. Eur J Pain 2004;8:18799.

7. Mikkelsson M, Salminen JJ, Kautiainen H. Non-specific musculoskeletal pain in preadolescents. Prevalence and 1-year persistence. Pain 1997;73:29-35.

8. Rethelyi JM, Berghammer R, Ittzes A, Szumska I, Purebl G, Csoboth C. Comorbidity of pain problems and depressive symptoms in young women: Results from a cross-sectional survey among women aged 15-24 in Hungary. Eur J Pain 2004;8:63-9.

9. Smedbraten BK, Natvig B, Rutle O, Bruusgaard D. Self-reported bodily pain in schoolchildren. Scand J Rheumatol 1998;27:273-6.

10. Perquin CW, Hunfeld JA, Hazebroek-Kampschreur AA, et al. The natural course of chronic benign pain in childhood and adolescence: A two-year population-based follow-up study. Eur J Pain 2003;7:551-9.

11. Laurell K, Larsson B, Eeg-Olofsson O. Headache in schoolchildren: Association with other pain, family history and psychosocial factors. Pain 2005;119:150-8.

12. Mack KJ. An approach to children with chronic daily headache. Dev Med Child Neurol 2006;48:997-1000. potential generalizability of the findings from our study sample. Due to the cross-sectional nature of the present study, causality could not be examined. We analyzed the impact of pain on childhood health; however, in reality, causality is likely to be multidirectional. Future research should include longitudinal studies to examine causality and the long-term implications of pain. In spite of the limitations of the present study, health care professionals, school administrators and teachers should consider the impact of pain on the ongoing health and wellbeing of children.

The primary emphasis of the present paper was the relationship between pain and self-reported health. We report that pediatric pain is associated with poor self-rated health, psychological symptoms and unhappiness with school experiences. Second, we demonstrate that such data can be obtained in a self-report manner using a modified version of the PEI-SF that included questions from the HBSC questionnaire. Children experiencing numerous pains of differing severity had a significant tendency to report adverse health experiences. This research provides a foundation for future longitudinal studies to examine the impact of pain on children's health.

ACKNOWLEDGEMENTS: The present study was supported by the New Emerging Team Grant from the Institute of Gender and Health (GHL - 63209) Canadian Institutes of Health (CIHR) [Principal Investigator - Dr Patricia McGrath].
13. Eccleston C, Bruce E, Carter B. Chronic pain in children and adolescents. Paediatr Nurs 2006;18:30-3.

14. Eccleston C, Crombez G, Scotford A, Clinch J, Connell H. Adolescent chronic pain: Patterns and predictors of emotional distress in adolescents with chronic pain and their parents. Pain 2004;108:221-9.

15. Campo JV, Bridge J, Ehmann M, et al. Recurrent abdominal pain, anxiety, and depression in primary care. Pediatrics 2004;113:817-24

16. Palermo TM, Kiska R. Subjective sleep disturbances in adolescents with chronic pain: Relationship to daily functioning and quality of life. J Pain 2005;6:201-7.

17. van Dijk A, McGrath PA, Pickett W, Van Den Kerkhof E. Pain prevalence in nine- to 13-year-old school children. Pain Res Manage 2006;11:234-40.

18. Currie C, Samdal O, Boyce W, Smith B, eds. Health Behaviour in School-aged Children: A World Health Organization CrossNational Study. Research Protocol for the 2001/02 Survey. Edinburgh: University of Edinburgh, 2002.

19. McGrath PA, Speechley KN, Seifert CE, et al. A survey of children's acute, recurrent, and chronic pain: Validation of the pain experience interview. Pain 2000;87:59-73.

20. Hartling L, Pickett W, Brison RJ. Derivation of a clinical decision rule for whiplash associated disorders among individuals involved in rear-end collisions. Accid Anal Prev 2002;34:531-9.

21. King A, Wold B, Tudor-Smith C, Harel Y. The health of youth. A cross-national survey. WHO Reg Publ Eur Ser 1996;69:1-222.

22. Hetland J, Torsheim T, Aaro LE. Subjective health complaints in adolescence: Dimensional structure and variation across gender and age. Scand J Public Health 2002;30:223-30.

23. Mikkelsson M, Salminen JJ, Sourander A, Kautiainen H. Contributing factors to the persistence of musculoskeletal pain in preadolescents: A prospective 1-year follow-up study. Pain 1998;77:67-72.

24. Boyce W. Young people in Canada: Their health and well-being. $<$ http://www.phac-aspc.gc.ca/dca-dea/publications/hbsc-2004/pdf/ hbsc_report_2004_e.pdf> (Version current at August 25, 2008). 


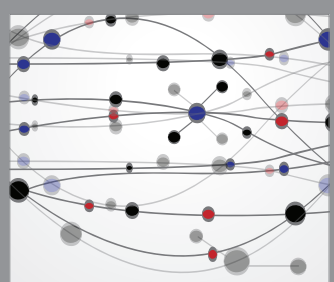

The Scientific World Journal
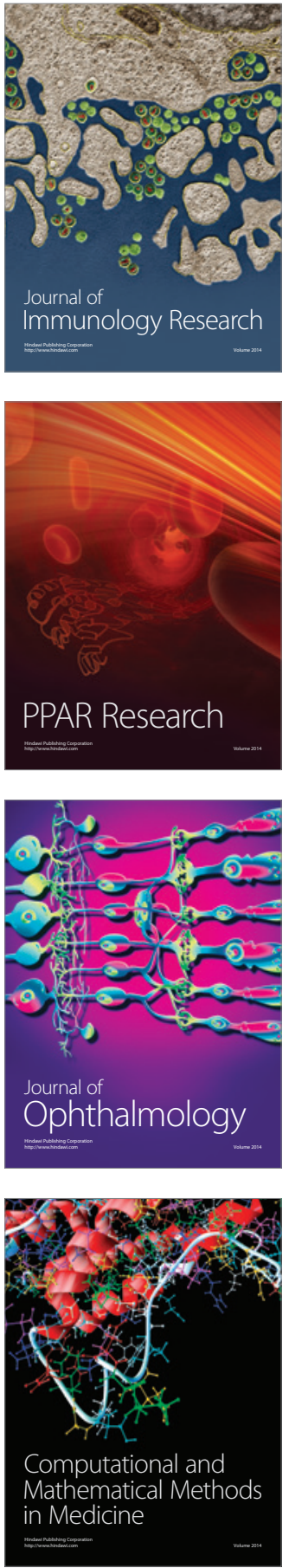

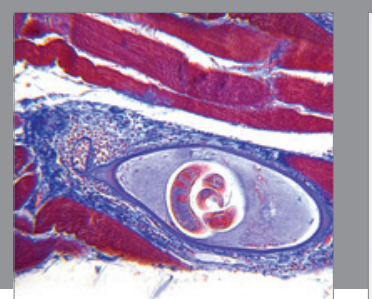

Gastroenterology Research and Practice

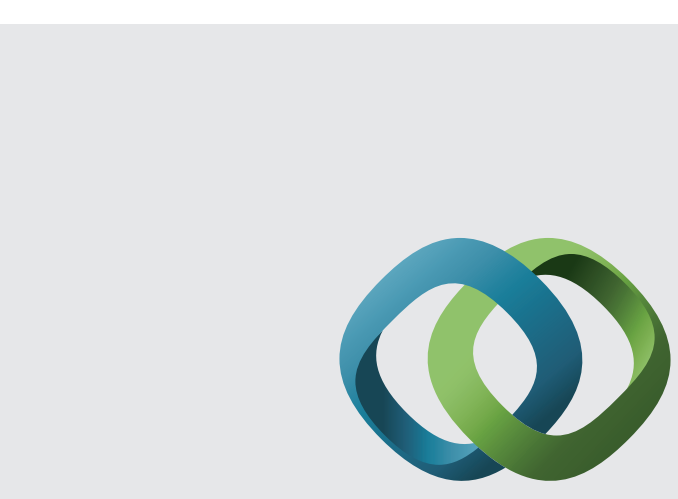

\section{Hindawi}

Submit your manuscripts at

http://www.hindawi.com
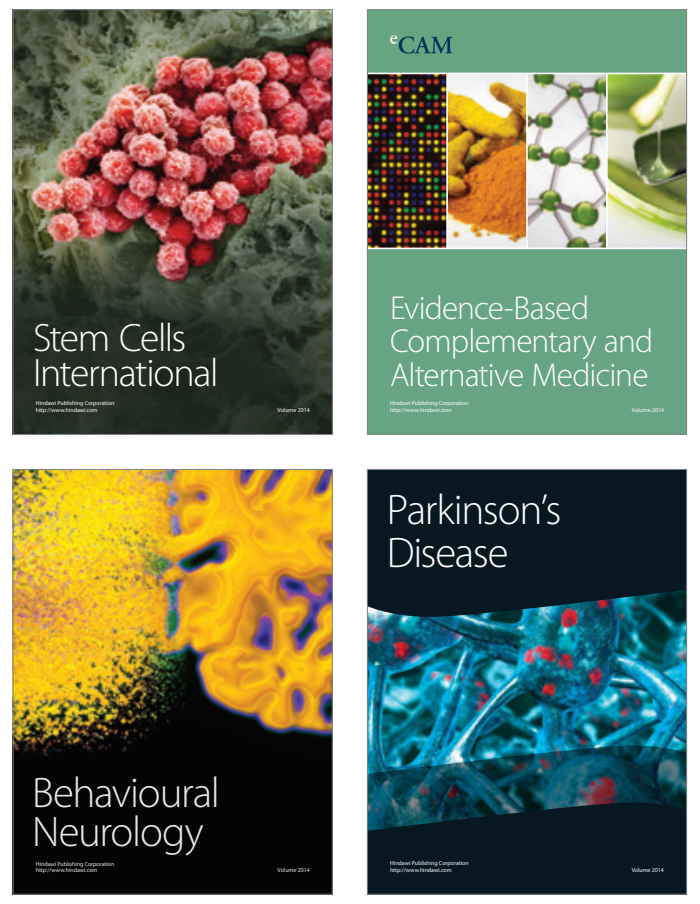
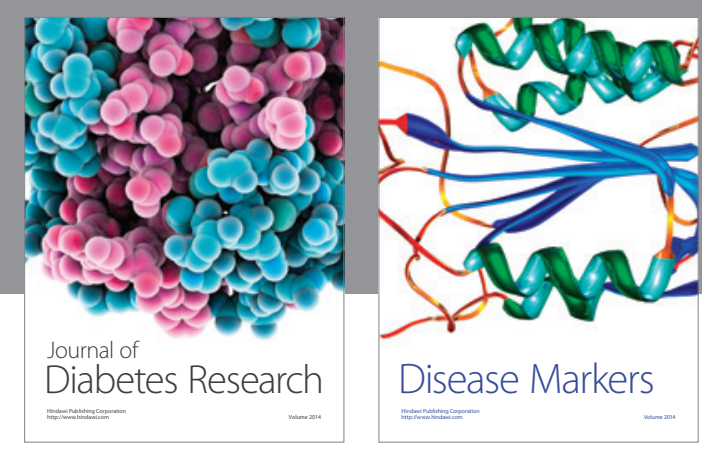

Disease Markers
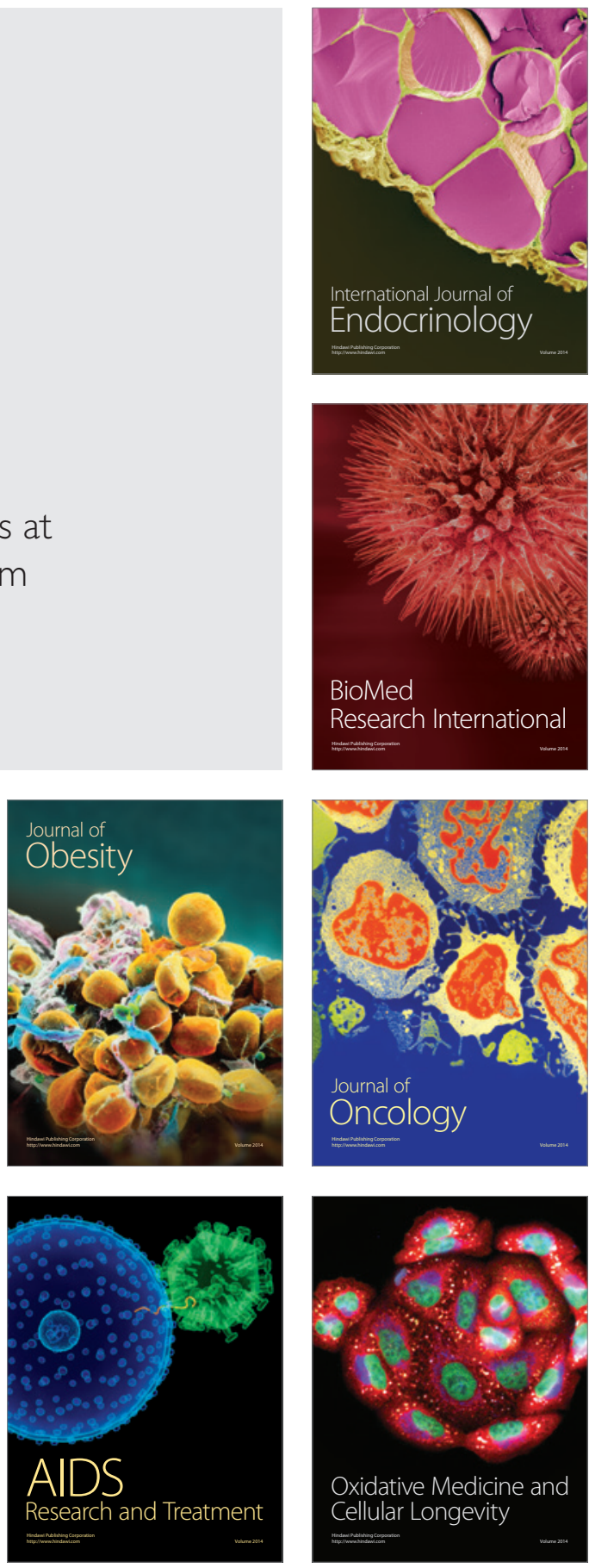